\title{
RECENT BRAZILIAN EXPERIENCE ON FARMER REACTION AND CROP RESPONSE TO FERTILIZER USE *
}

E. MALAVOLTA* *

M. ROCHA $\star \star \star *$

SUMMARY

(1) In the period $1965 / 77$ fertilizer consumption in Brazil increased nearly fifteen foild from circa 200,000 tons of $\mathrm{N}+\mathrm{P}_{2} \mathrm{O}_{5}+\mathrm{K}_{2} \mathrm{O}$ to 3 million tons. During the fifteen years extending from 1950 to 1964 usage of the primary macronutrients was raised by a factor of 2 only.

(2) Several explanations are given for the remarkable increase, namely: an

experimental background which supplied data for recommendations of rates, time and type of application; a convenient governmental policy for minimum prices and rural credit; capacity of the industry to meet the demand of the fertilizer market; an adequate

* Recebido para publicação em 21.12.1978. Apresentado mediante convite no ASA Symposium sobre "Transfer of technology to farmers of small 1 and holdings", Chicago, Ill, EUA, 4.12.1978. ** Dep. Química e CENA, E.S.A. "Luiz de Queiroz", USP. *** ANDA, São Paulo. 
mechanism for the diffusion of the practice of fertilizer use to the farmer.

(3) The extension work, which has caused a permanent change in the aptitude towards fertilization, was carried out in the traditional way by salesmen supported by a technical staff, as well as by agronomists of the official services.

(4) Two new programs were started and conducted in a rather short time, both putting emphasis on the relatively new technology of fertilizer use.

(5) The first program, conducted in the Southern part of the country, extended $1 \mathrm{ab}$ and green house work supplemented by a few field trials to small land owners - the so called "operação tatú" (operation armadillo).

(6) The seconde program, covering a larger problem area in the Northeast and in Central Brazil, began directly in field as thousands of demonstrations and simple experiments with the participation of local people whose involvement was essential for the success of the initiative; in this case the official extension services, both foreign and national sources of funds, and universities did participate under the leadership of the Brazilian Association for the Diffusion of Fertilizers (ANDA).

(7) It is felt that the Brazilian experience gained thereof could be useful to other countries under similar conditions. 


\section{INTRODUCTION}

Developing countries, as a rule, face the problem of having agricultural production levels which must be sufficient for:

- covering the needs for food, fiber for a growing population;

- proving raw material for food preservation and transformation industries;

- leaving surpluses for export - quite often the only dependable source of hard currency needed for the desired industrialization.

With few exceptions, population pressure and misuse of soil and water resources in the past, in the present as well as in the foreseable future have led to only one alternative for reaching the three goals, namely.

- raising yield per unit of area or productivity, since agricultural land has usually very little room for expansion; production per hectare, on the other hand, usually shows plenty of room for increasing.

It is generally accepted that the use of fertilizers and amendments (mainly liming materials in the humid tropics and subtropics) present the

- cheapest,

-fastest, and

-major

way for increasing productivity. Plenty of worldwide evidence give support for the statement:

(1) in the initial segment of the fertilizer response curve ratios benefit/cost are as rule more favourable - a situation which prevails in the developing countries; it 
is adequate to quote PARKER \& NELSON (1966) - their data clearly show that in many cases investments in fertilizer plants are cheaper than those in more agricultural land - if this is available;

(2) of the three media from which plants derive their nutrients, soil, water, and air, the first one is the easiest to change making it more productive when the need arises; and, provided the basic information and the means for implementing thereof are available, this can be accomplished in no time :

(3) data coming from different regions - from India to Brazil - show very consistently that fertilizers (and to some extent liming materials) are the single input which is capable of giving the highest increases in yield, more than the improved seed, the irrigation practice, pest and disease control, and so on - 30-40\% as average; recent experience has shown, furthermore, that "there is no miracle seed without fertilizers".

One topic which was briefly mentioned in item (2) above should be dealt with in more detail; the idea of the succession

research $\rightleftarrows$ extension $\rightleftarrows$ implemention $\rightleftarrows$ yield $\longrightarrow$ profit was introduced; this chain of orderly events, as applied to fertilizer and lime use, is further illustrated in Figure 1.

The efficient use of fertilizers and liming materials may, therefore, be limited at different steps: lack of knowledge; deficiency in the transfer of information to the farmer; lack of means for using the information eventually made available. 
This matter has been discussed previously (SEGELMAN, 1962; ARNON, 1964, 1978; VON STEINER, 1972; MALAVOLTA, 1973, 1977; REVELLE, 1974; WYBENGA, no date).

FERTILIZER USE

Figure 2 shows in a simplified fashion the evolution in fertilizer consumption in Brasil in the years 1950 to 1977. One can easily see the following:

- the overall curve can be broken down into two nearly straight lines;

- the two straight lines show very different slopes;

- the initial slope, corresponding to the period 1950-1964 is much less pronunced than the seconde one.

Several attempts have been made to further split both slopes according to reasons which would explain, on quantitative terms, the observed differences in trends; the limited number of points (years) has prevented that useful information could be safely drawn. There are, however, sufficient data pointing towards factors or inputs which help to explain why the change in slope took place.

An attempt to shosw this in a rather arbitrary way is presented in Figure 3 .

Slope $\alpha$ was undoubtedly the result of a summation (and, probably interaction) of the following components whose relative contribution is roughly indicated in the graph:

(1) existing recommendations for fertilizer use by the farmer based on previous research work; 
(2) limited transfer of said information by traditional extension activities provided for by official agencies a great deal complemented by fertilizer dealers and manufacturesrs in close contact with the man in the field;

(3) very limited agricultural policy geared for fertilizer use.

There is little doubt that in this initial phase further development in fertilizer consumption was prevented for lack of more adequate extension work and, to a larger degree, by the nearly absent governmental policy in terms of credit (or subsidies or other incentives), and of minimum prices for agricultural commodities.

The same components apply in the case of the steeper slope $B ;$ in this case, however, the two bottlenecks were widened thus permitting a better flow of information to the farmer and higher fertilizer use; the latter was made possible thanks to a set of favourable cicumstances, namely,

- availability of fertilizer supplied in time and space by the industry, either through local production or imports;

- easier terms (and more abundant) rural credit destined for fertiliers and liming materials, although limitations still exist;

- more effective policy with regard to minimum prices for the agricultural products.

This subject has been discussed elsewhere (BELLOTTI, 1972; MALAVOLTA, 1973).

The role played by extension in the phenomenon will be discussed next. Emphasis will be put into two programs; one of them was carried, in a way, from without, that is, from the field to the labo- 
ratory; the second was conducted from within - from the laboratory to the field. Despite differences in conception and implementation, favourable results were obtained in both cases.

\section{ANDA PROJECT}

ANDA stands for National Association for the Diffusion of Fertilizers which was founded by a group of representatives of the industry 12 years ago. Today 95 per cent or more of the Brazilian fertilizer industry including the state controlled ones, take part. Financing for operation is provided for by the industry itself which supply funds in proportion to the volume of sales.

ANDA's activities are not restricted, however, to simple extension (at the farmers, producers or governmental levels). It is committed to other aspects of fertilizer production, import, marketing, distribution, development and use. Through seminars, meetings, workshops and task forces has played a role in the establishment of official policies, including the present laws which control the fertilizer market. Due to its initiative funds have been made available for the recent establishment of a research center on fertilizer technology (CEFER). (See ANDA, 1968; GONÇALVES, 1976).

The project for the large scale extension on fertilizer use, coordinated by ANDA, was supported to a large degree by the official agencies as well as by private and governmental banks; planning, conduction and evaluation depended upon the collaboration obtained in the universities, both state and federal; the Food and Agriculture Organization of the United Nations also participated as part of the "freedom from hunger" compaign (VEGA, 1972; ANDA, 1978).

At the outset (The year 1969) the following 
position was assumed with regard to ends and means;

(1) the main objective was raising productivity through the use of fertilizers and other inputs which might limit yield;

(2) experiments and trials should concentrate in food crops;

(3) the design should be simple enough in order to permit visual conclusions to be drawn by the interested farmers;

(4) the results should be evaluated from the point of view of the economics of fertilizer use;

(5) the demonstrations and simple trials should be conducted in cultivators land, being a way to teach the farmer the proper use of fertilizers with respect to rate, timing and technique of application;

(6) a number large enough of trials should be carried in order to permit a safe extrapolation of results obtained after the statistical analysis had been made.

In the first seven years of the project efforts were concentrated in the states of Central Brazil, namely: Espírito Santo, Minas Gerais, Goiás, (South), and Mato Grosso (South) covering an area of 1.1 miliion square kilometers represented by 300 counties, roughly. More than 110 short courses attended by 2040 extension agents and field technicians were offered beforehand in order to provide basic training for the installation, conduction and in situ evaluation of results. The booklet prepared by FAO con "Courses for training on fertilizer use" was used in order to get uniformity in procedures. Statistical analyses were conducted at the E.S.A. "Luiz de Queiroz", University of São Paulo, Piracicaba, São Paulo. 
TWO SIMPLE DESIGNS WERE USED

$$
\begin{aligned}
& \text { demonstrations - plots receiving the standard } \\
& \text { pratices used in the region; } \\
& \text { plots receiving all inputs } \\
& \text { and recommended agricultural } \\
& \text { practices except fertilization; } \\
& \text { ditto plus fertilization (and } \\
& \text { sometimes liming); } \\
& \text { experiments - } \text { the following treatments were } \\
& \text { used } \\
& \text { (1) } \operatorname{control} \text { - without fertilizer } \\
& \text { (2) } \mathrm{N}_{2} \mathrm{P}_{2} \mathrm{~K}_{2} \\
& \text { (3) } \mathrm{N}_{1} \mathrm{P}_{2} \mathrm{~K}_{2} \\
& \text { (4) } \mathrm{N}_{0} \mathrm{P}_{2} \mathrm{~K}_{2} \\
& \text { (5) } \mathrm{N}_{2} \mathrm{P}_{0} \mathrm{~K}_{2} \\
& \text { (6) } \mathrm{N}_{2} \mathrm{P}_{1} \mathrm{~K}_{2} \\
& \text { (7) } \mathrm{N}_{2} \mathrm{P}_{1} \mathrm{~K}_{2} \\
& \text { (8) } \mathrm{N}_{2} \mathrm{P}_{2} \mathrm{~K}_{0}
\end{aligned}
$$

when indicated, additional treatments were used in conjunction with $\mathrm{N}_{2} \mathrm{P}_{2} \mathrm{~K}_{2}$, that is liming, micronutrients, etc.

Table l, taken from MOYA GARAY (1978) shows the distribution of demonstrations and trials according to crops and regions. The numbers for a given crop reflect to some extent the relative economical importance for a given place.

Since the acceptance of a given practice depends to a large degree on seeing it work, field days (accompanied many times by the convenient refreshments) were used throughout as shown in Table 2. By this way farmers were taught: elements of fertilizer use; benefits thereof. All phases of 
the trials and experiments could be accompanied, including harvesting so that the chances of getting a permanent change of attitude could (hopefully) be increased and the results obtained should have a lasting effect.

Response curves to the three elements usually fit the equation

$$
\begin{aligned}
& y=A\left[1-10^{-c(x+b)}\right] \text { where } \\
& y=\text { yield due to } \\
& x=\text { rate of fertilizer }(\mathrm{kg} \text { element/ha) } \\
& A, b, c=\text { parameters; }
\end{aligned}
$$

the most economical rate of fertilizer was given by the equation (PIMENTEL GOMES, 1969):

$$
\begin{aligned}
& x^{*}=\frac{1}{2} x_{\mu}+\frac{1}{c} \log \frac{w_{\mu}}{t x_{\mu}} \text { where } \\
& x^{*}=\text { most economical dosage } \\
& x_{\mu}=\text { rate of fertilizer giving } \\
& \mu=\text { increase in yield over control } \\
& w=\text { unit cos of product } \\
& t=\text { unit price of fertilizer; }
\end{aligned}
$$

due to fluctuation in the cost of product and price of fertilizers different values of $x^{*}$ for each crop in each state were calculated by making the $\mathrm{w} / \mathrm{t}$ ratio vary within accepted ranges.

Average results for a few selected crops are presented in Table $3 ;$ it is worth mentioning at this point that maximum rates of fertilizer applied were usually 45-90-45 which fall within the limits of dosages recommended. One can see that increases varied from a

low 698 for soybeans to a

high $246 \%$ for corn,

a supposedly unresponsive crop. 
A summary of recommendations (see MALAVOLTA \& ROMERO, 1975) is presented in Table 4. These data should be considered as rough averages for fertilizer use in the region of the study giving in idea of likely responsiveness to the three macronutrients.

Figure 4 presents the evolution of fertilizer use (tons of products) in the Central region of Brazil in the period covered by the experiments. It is tempting to compare these data with changes observed in Brazil during the same time: it is clear that in the region consumption has increased at a faster rate than in the country as a whole; there was, therefore, a larger expansion in the market in relative terms.

Obeying the same general lines, a project was started in the northeast in the States of Maranhão, Piauí, Ceará, Rio Grande do Norte, Paraíba, Pernambuco, Alagoas, Sergipe and Bahia covering 313 counties representing an area of $1.6 \mathrm{mili}$ ion $\mathrm{km}^{2}$ which corresponds to $20 \%$ of the country.

Tables 5 and 6 give, respectively, distribution of trials and demonstrations according to states and degree of farmer involvement in the program.

Average results obrained in the Northeast in terms of response are given in Table 7 ; recommendations appear in Table 8.

In the experimental period fertilizer consumption in the Northeast has increased at a much faster rate than in the rest of Brazil as shown in Figure 4.

OPERATION TATE

"Tatú" is the Brazilian name for armadillo, an animal which digs holes in the ground - the soil specialists did make many holes in the ground to get soil samples for analyses in the laboratories. 
This explains the nickname given by the small farmers themselves for the project located mainly in the South of Brazil, Estado do Rio Grande do Sul, and later extended to the neighboring state of San ta Catarina.

According to KLAMT (1970) "operation tatú" was defined as "an ample program of rural extension with the objective of bringing to the farmer, in a direct and massive fashion, new technology for agricultural production, with special emphasis in the neutralization of soil acidity and in the correction of soil fertility. Farms involved fell nearly 75 per cent in the size range of 10-100 hectares.

The program was carried out in collaboration with credit and extension agencies under the leadership of the College of Agriculture of the Federal University of Rio Grande do Sul, which at the beginning (1969) had an AID contract with the University of Wisconsin, Madison, Wis.

As start several premises had been identified a working hypothesis for the whole venture -

(1) the soils of the region were poor in nutrients, especially in phosphorus (P)

(2) the soils of the region were usually very acidic;

(3) cultural practices were deficient;

(4) previous experimental results had already shown that yields could be increase dramatically through fertilization and liming See Table 9 .

The objetives were set as follows:

(1) adoption by the farmer of the new technology for soil and crop management; 
(2) changes in the mining type of agricultural practice towards a more advanced one;

(3) raise in the socio-economical level of the small and medium farmer;

(4) overall raise in agricultural productivity of the region.

To reach such objectives a list of prerequisites was organized, namely:

(1) research on soil fertility to provide sound recommendations for the use of fertilizer and liming materials;

(2) a training program of extension agents to assist the farmer;

(3) financing under long and favourable terms to be provided by banks;

(4) a network of cooperatives or rural association for marketing the agricultural products ;

(5) involvement of governmental representatives, rural leaders, technicians and the whole community;

(6) availability of inputs.

Here also demonstrations and field days were organized.

Lab, field and greenhouse work allowed for recommendations to be made with regard to fertilizer and lime use. Figure 5 gives calibration curves for limestone application and for rates of $\mathrm{P}_{2} \mathrm{O}_{5}$ and $\mathrm{K}_{2} \mathrm{O}$, respectively, according to TEDESCO (1978) and GOEPFERT (1977).

"Operation armadillo" has led so far to 
results and consequences.

Main results can be summarized as follows -

(1) ready and lasting acceptance of the practice of lime and fertilizer use as shown by the increasing number of small farmers involved (Table 10) due to the striking differences in yield (Table 11); the so called "corrective fertilization" destined to increase soil fertility through the use of relatively large rates of $P$ and $K$ which are broadcast and plowed in, a practice long forgotten in Brazil, is now routine.

(2) growing number of soil samples sent to analysis;

(3) larger and easier flow of capital resources for rural operations (Table 10).

It must be kept in mind, however, that the success of the operation was not due only to lime and fertilizer (although these were the main responsible) - other inputs were not limiting yields being supplied as part of a whole technological packet.

As consequences, the following should be underlined:

(1) increase in the use of fertilizers as indicated by the per cent of Brazilian consumption which corresponds to the South of the country

$$
\begin{aligned}
& 1969-198 \\
& 1977-358
\end{aligned}
$$

as in other instances the raise in fertilizer use could not be credited only to the extension program dealt with; its success however helped the development of the 
industry and to a change in ideas both at the governmental level as well as in the financing agencies;

(2) increase in the use of liming materials

$$
\begin{aligned}
& 1966 \text { - less than } 100 \text { thousand tons } \\
& 1977 \text { - nearly } 3 \text { million tons; }
\end{aligned}
$$

(3) the soybean boom - the use of fertilizer and liming materials permitted the expansion of acreage and the raise in productivity (up $500 \mathrm{~kg} / \mathrm{ha}$ ) by allowing (along with other practices such as seed inoculation) the genetical potential of the cultivars to be more fully realized.

RESUMO

No periodo de 1965-77 houve um aumento de 15 vezes no consumo brasileiro de fertilizantes. São discutidas as causas - pesquisa, política, agrícola, disponibilidade de ferti lizantes. E dada ênfase a dois programas especiais de exten são: a "operação tatu" desenvolvida no Sul do País e o programa coordenado pela ANDA no Centro e no Nordeste.

\section{LITERATURE CITED}

ANDA, 1978. Programa de ferilizantes no Brasil - Projeto FAO/ABCAR/AMDA, 1969-1976. 26 pages, mimeo., São Paulo.

ANDA, 1968. Brazilian Fertilizer Association - Objectives and Programs for Fertilizer Development in Brazil, São Paulo.

ARNON, I., 1964. The role of agricultural research in developing countries. World Crops (Sept.): 20-23.

ARNON, I., 1978. Fertilizer use as a lead practice in modernizing agriculture. Potassium Research - Review and Trends, IPI, Bern, pages 118-125. 
BELlOTTI, P.V., 1970. Perspectivas da indústria de fertilizantes no Brasil. U.N. Indus. Dvlpmt. Org. Mtg. (S. Pau10), 29 pages, mimeo.

GOEPFERT, C.F., 1977. Situação nutricional da cultura da so ja em alguns solos do Rio Grande do Sul. IPAG 20 Inf. 18: 19-26.

GONÇALVES, J.D., 1976. ANDA - Nove anos de atividade, 12 pa ges, mimeo, S. Paulo.

KLAMTE, E., 1970. Programação e execução de projetos "Opera ção Tatü". Fac. Agr. Vet., UFRGS, Bol. Tec. 5.

MALAVOLTA, E., 1977. Adubos, produção agrỉcola e desenvolvi mento. I Sem. sobre Fertilizantes no Norte e Nordestē (Salvador), 27 pages, mimeo.

MALAVOLTA, E., 1973. Fertilizer policy in the developing countries - The case of Brazil. An. E.S.A. "Luiz de Quei roz" 30:293-304.

MALAVOLTA, E., 1977. Tendências na adubação no Brasil. 0 Solo $69(2): 50-54$.

MALAVOLTA, E.; ROMERO, J.P. (Editors), 1975. Manual de Adubação, second edition, Publ. by ANDA, S. Paulo.

MOYA GARAY, L.A.C., 1978. O programa de demonstração agríco la de ANDA. Paper presented at the "Primeira Conferênciā sobre el Uso de Fertilizantes", Mexico, 15 pages, mimeo.

PARKER, F.W.; NELSON, L.B., 1966. More fertilizer for more food. In: Prospects of the World Food Supply, A Symposium. Nat1. Acad. of Sciences, Washington.

REVELLE, R., 1874. Food and population. Sci. Amer. 231(3): $161-170$.

SEGELMAN, G., 1962. Factors determining the role of fertilizers in underdeveloped countries. UN Conf. Appl. Sci. Technol. Benefit of the Less Developed Countries (Geneva), E/Conf. 39/d/51, 3 pages. 
TEDESCO, M.J., 1978. Acidez e calagem. Curso atual. Ferti lidade do Solo (Jaboticabal), 24 pp., mimeo.

VEGA, J. de La., 1972. Programa de Fertilizantes FAO-Ministério da Agricultura - Projeto FAO/ANDA/ABCAR. 24 pp., mi meo., Rio de Janeiro.

VON STEINER, E.B., 1972. Problems of fertilizer use in Latin America. Pontificial Acad. Sci. Scripta Varia 38:189-212 .

WYBENGA, J.M., No date. Alterations in fertilizer use and provision related to the production of a highly developed and diversified agriculture. ISMA Sem. (S.Paulo), 15 pages, mimeo. 
Table 1 - Demonstration and trials conducted in the Central region of Brazil (1969/67).

\begin{tabular}{|c|c|c|c|c|c|}
\hline \multirow{2}{*}{ Crop } & \multicolumn{5}{|c|}{ State } \\
\hline & M.Gerais & Goiās & M. Grosso & E.Santo & Total \\
\hline Pineapple & - & - & - & 27 & 27 \\
\hline Cotton & 152 & 87 & 32 & 11 & 282 \\
\hline Peanuts & 29 & 34 & - & 14 & 77 \\
\hline Rice & 832 & 634 & 166 & 44 & 1676 \\
\hline Banana & - & - & - & 15 & 15 \\
\hline Potato & 92 & - & - & 60 & 152 \\
\hline Sugar-cane & 11 & - & - & - & 11 \\
\hline Beans & 460 & 139 & 59 & 98 & 756 \\
\hline Castor beans & 39 & - & - & 10 & 49 \\
\hline Cassava & 72 & - & - & - & 72 \\
\hline Corn & 961 & 279 & 107 & 124 & 1471 \\
\hline Soy bean & 511 & 250 & 76 & 13 & 850 \\
\hline Grain sorghum & 127 & 101 & 6 & - & 234 \\
\hline Wheat & - & - & 8 & - & 8 \\
\hline Total & 3286 & 1524 & 454 & 416 & 5650 \\
\hline
\end{tabular}


Table 2 - Involvement of farmes, Central Brazil (1969/76).

\begin{tabular}{lcc}
\hline State & Number of field days & $\begin{array}{c}\text { Number of partici- } \\
\text { pants }\end{array}$ \\
\hline Minas Gerais & 2060 & 43230 \\
Goiās & 268 & 11723 \\
Mato Grosso & 61 & 1325 \\
Espírito Santo & 76 & 996 \\
\hline Total & 2465 & 57274 \\
\hline
\end{tabular}

Table 3 - Average results obtained in the Central Brazil.

\begin{tabular}{lccc}
\hline \multirow{2}{*}{ Crop } & \multicolumn{3}{c}{$\mathrm{kg} / \mathrm{ha}$} \\
\cline { 2 - 4 } & Local average & Maximum economical yield & \%increase \\
\hline Rice & 1282 & 2783 & 117 \\
Corn & 1400 & 4853 & 246 \\
Soybeans & 1060 & 1793 & 69 \\
Beans & 500 & 1153 & 132 \\
\hline
\end{tabular}


Table 4 - Summary of recommendations for the use of fertilizers in Central Brazil.

\begin{tabular}{llll}
\hline \multirow{2}{*}{ Crop } & \multicolumn{3}{c}{$\mathrm{kg} / \mathrm{ha}$} \\
\cline { 2 - 4 } & $\mathrm{N}$ & $\mathrm{P}_{2} \mathrm{O}_{5}$ & $\mathrm{~K}_{2} \mathrm{O}$ \\
\hline
\end{tabular}

Corn

$w / t(N)=0,10$

$w / t\left(P_{2} \mathrm{O}_{5}\right)=0,12$

$w / t\left(R_{2} 0\right)=0,30 \quad 45$

Beans

$w / t(N)=0,30$

$w / t\left(P_{2} \mathrm{O}_{5}\right)=0,35$

$\mathrm{w} / \mathrm{t}\left(\mathrm{K}_{2} \mathrm{O}\right)=0,70 \quad 17$

$30 \quad 0$

Soybeans

$w / t\left(P_{2} \mathrm{O}_{5}\right)=0,40$

$w / t\left(K_{2} 0\right)=0,60$ ?

89

71

Rice

$w / t(N)=0,30$

$w / t \quad\left(P_{2} \mathrm{O}_{5}\right)=0,35$

$w / t\left(K_{2} 0\right)=0,70 \quad 0$ 
Table 5 - Démonstration and trials conducted in the Northest Brazi1 (1972/76).

\begin{tabular}{llllllllllll}
\hline Crop & \multicolumn{11}{c}{ State } \\
\cline { 2 - 4 } & MA & PI & CE & RN & PB & PE & AL & SE & BA & Total
\end{tabular}

\begin{tabular}{|c|c|c|c|c|c|c|c|c|c|c|}
\hline Pineapple & - & - & - & - & 16 & - & - & - & 30 & 64 \\
\hline Cotton & 120 & 96 & 535 & 390 & 369 & 153 & 101 & 43 & 120 & 1927 \\
\hline Peanuts & - & - & - & - & 16 & - & - & 10 & - & 26 \\
\hline Rice & 159 & 138 & 95 & 13 & 65 & 28 & 20 & 58 & 43 & 619 \\
\hline Potato & - & - & - & - & 16 & - & - & 10 & - & 26 \\
\hline Sugar cane & - & - & - & - & 39 & 157 & 44 & - & - & 240 \\
\hline Coffee & - & - & $44^{\circ}$ & - & - & - & - & - & - & 44 \\
\hline Onion & - & - & - & - & - & 28 & - & - & - & 28 \\
\hline Coconut & - & - & - & - & 14 & - & - & - & - & 14 \\
\hline Citrus & - & - & - & - & - & - & - & 36 & - & 36 \\
\hline Beans & 142 & 124 & 107 & 108 & 57 & 115 & 78 & 56 & 128 & 915 \\
\hline Tabacco & - & - & - & - & - & - & 22 & - & - & 22 \\
\hline Cassava & - & - & 78 & 155 & 200 & 51 & - & 8 & - & 492 \\
\hline Corn & 127 & 144 & 77 & 69 & 176 & 57 & 68 & 45 & 164 & 927 \\
\hline Soybeans & - & - & 50 & - & - & - & - & - & 34 & 84 \\
\hline Tomato & 15 & - & 12 & - & - & - & - & - & - & 27 \\
\hline Banana & 30 & - & - & - & - & - & - & - & - & 30 \\
\hline Total & 583 & 502 & 1082 & 735 & 952 & 589 & 333 & 256 & 519 & 5561 \\
\hline
\end{tabular}


Table 6 - Farmer involvement in field days, Northeast Brazil (1972-76).

Maranhão \& Piaui

Ceará, Rio Grande do Norte \& Paraiba

Pernambuco

34714

Alagoas \& Sergipe

4024

Bahia

13014

1276

Tota1

72823

Table 7 - Average results obtained in Northeastern Brazil.

\begin{tabular}{|c|c|c|c|}
\hline \multirow{2}{*}{ Crop } & \multicolumn{3}{|c|}{$\mathrm{kg} / \mathrm{ha}$} \\
\hline & Local average & Max. economical & $\%$ increase \\
\hline Corn & 930 & 3026 & 225 \\
\hline Beans & 350 & 915 & 161 \\
\hline Rice & 1200 & 3111 & 159 \\
\hline Cassava & 12000 & 26060 & 117 \\
\hline Sugar Cane & 42000 & 87028 & 107 \\
\hline $\begin{array}{l}\text { Cotton } \\
\text { (perennial) }\end{array}$ & 300 & 948 & 216 \\
\hline Peamut & 900 & 2036 & 126 \\
\hline
\end{tabular}


Table 8 - Summary of general recommendations for the use of fertilizers in Northeastern Brazil.

\begin{tabular}{llll}
\hline Crop & $\mathrm{N}$ & $\mathrm{P}_{2} \mathrm{O}_{5}$ & $\mathrm{~K}_{2} \mathrm{O}$
\end{tabular}

Corn

$$
\begin{aligned}
& w / t(N)=0,10 \\
& w / t\left(\mathrm{P}_{2} \mathrm{O}_{5}\right)=0,12 \\
& w / t\left(\mathrm{~K}_{2} \mathrm{O}\right)=0,30
\end{aligned}
$$

Beans (Vigna)

$$
\begin{aligned}
& w / t(N)=0,30 \\
& w / t\left(\mathrm{P}_{2} \mathrm{O}_{5}\right)=0,35 \\
& w / t\left(\mathrm{~K}_{2} \mathrm{O}\right)=0,70
\end{aligned}
$$

\section{Cassava}

$$
\begin{aligned}
& w / t(N)=0,04 \\
& w / t\left(P_{2} \mathrm{O} 5\right)=0,045 \\
& w / t\left(\mathrm{~K}_{2} \mathrm{O}\right)=0,090
\end{aligned}
$$

Cotton (perennial)

$$
\begin{aligned}
& w / t(N)=0,60 \\
& w / t\left(\mathrm{P}_{2} \mathrm{O}_{5}\right)=0,70 \\
& w / t\left(\mathrm{~K}_{2} \mathrm{O}\right)=1,40
\end{aligned}
$$

Rice

$$
\begin{aligned}
& w / t(N)=0,30 \\
& w / t\left(\mathrm{P}_{2} \mathrm{O}_{5}\right)=0,35 \\
& w / t\left(\mathrm{~K}_{2} \mathrm{O}\right)=0,70
\end{aligned}
$$

\section{Sugar cane}

$w / t(N)=0,02$

$w / t\left(\mathrm{P}_{2} \mathrm{O}_{5}\right)=0,025$

$w / t\left(\mathrm{~K}_{2} \mathrm{O}\right)=0,050$ 
Table 9 - Response to fertilizers and liming by various crops in Rio Grande do Sul (kg/ha).

\begin{tabular}{lrcr}
\hline Crop & \multicolumn{3}{c}{ Treatments } \\
\cline { 2 - 4 } & Control & Fertilizer & $\begin{array}{c}\text { Fertilizer } \\
+ \text { lime }\end{array}$ \\
\hline Corn & 2400 & 5190 & 6560 \\
Wheat & 800 & 1500 & 2000 \\
Soybean & 1200 & 2500 & 3200 \\
Forage (dimatter) & 2000 & 4000 & 12000 \\
\hline
\end{tabular}

Table 10 - Some indicators of operation armadillo.

\begin{tabular}{lrrrr}
\hline Year & $\begin{array}{c}\text { Number of } \\
\text { farmers }\end{array}$ & $\begin{array}{c}\text { Limestone } \\
\text { (tons) }\end{array}$ & $\begin{array}{c}\text { Fertilizer } \\
\text { (tons) }\end{array}$ & $\begin{array}{c}\text { Resources } \\
\text { (Cr } \$)\end{array}$ \\
\hline 67 & 91 & 334 & 19 & 22500 \\
68 & 2144 & 17281 & 1783 & 1500000 \\
69 & 3075 & 43140 & 7140 & 3500000 \\
\hline
\end{tabular}


Table 11. A comparison between average state and yields following recommendations (kg/ha).

\begin{tabular}{lccc}
\hline Crop & Average & Obtained & $\%$ increase \\
\hline Rice & 2600 & $7000-9800$ & $169-277$ \\
Corn & 1100 & $6000-7400$ & $445-573$ \\
Wheat & 900 & $2800-3900$ & $211-333$ \\
Soybean & 1200 & $3000-3500$ & $150-192$ \\
Beans & 800 & 1500 & 552 \\
Potato & 4600 & 30000 & $289-775$ \\
Pasture (meat) & $40-90$ & 350 & \\
\hline
\end{tabular}




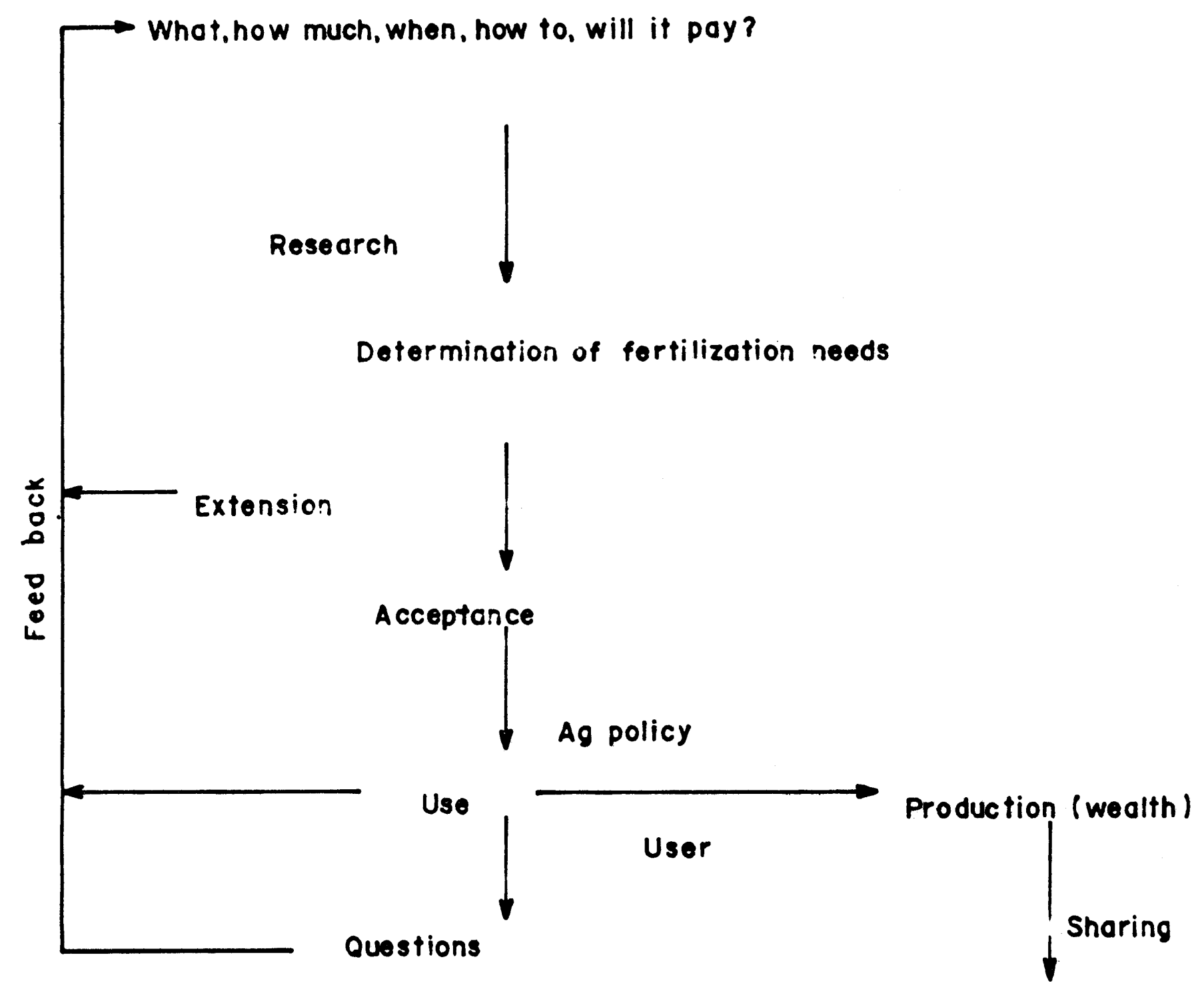

Well being

Figure 1 - The role of research on fertilizer, extension and $\mathrm{Ag}$ policy in agricultural production. 


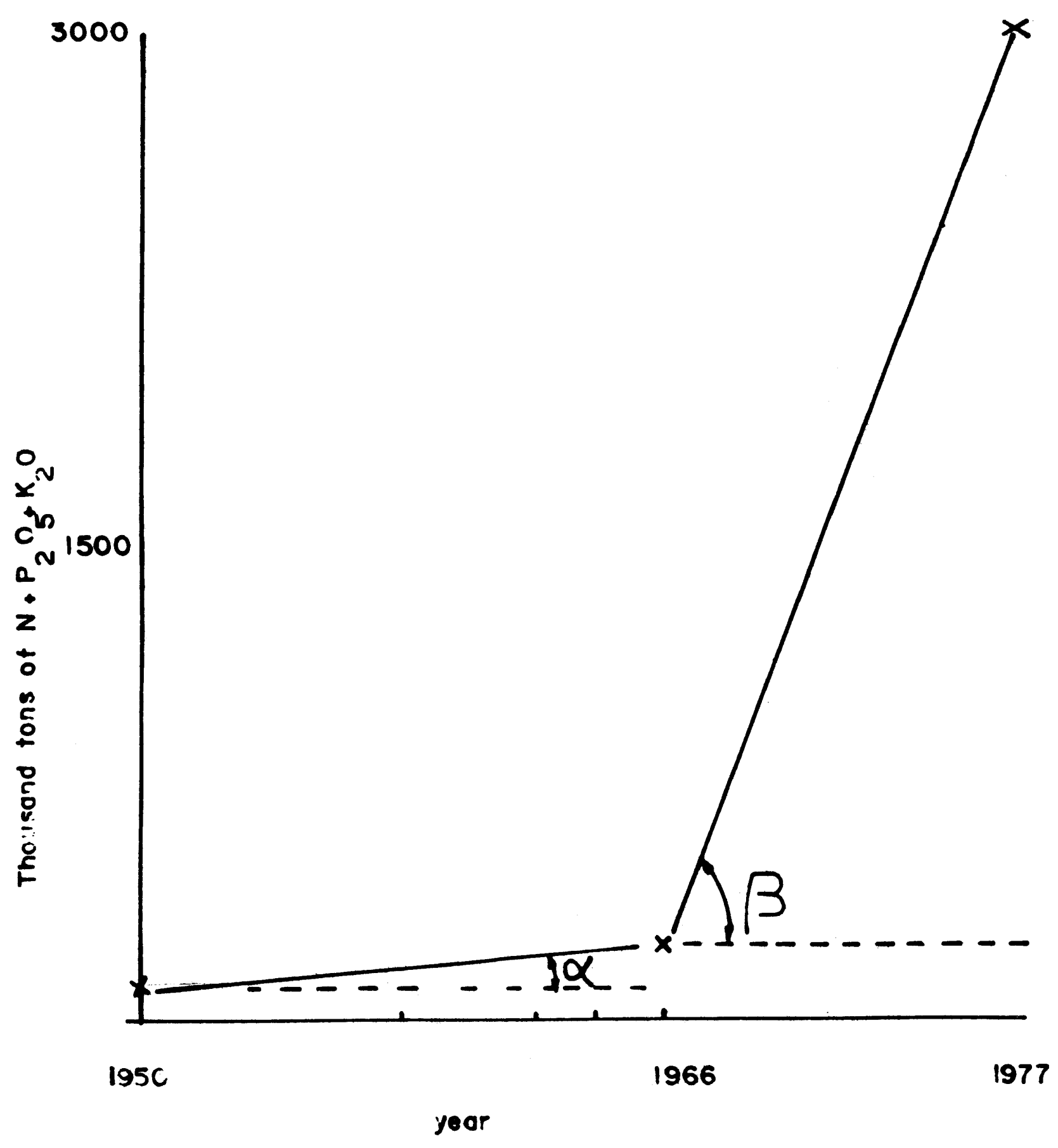

Figure 2 - Evolution of fertilizer use in Brazil. 

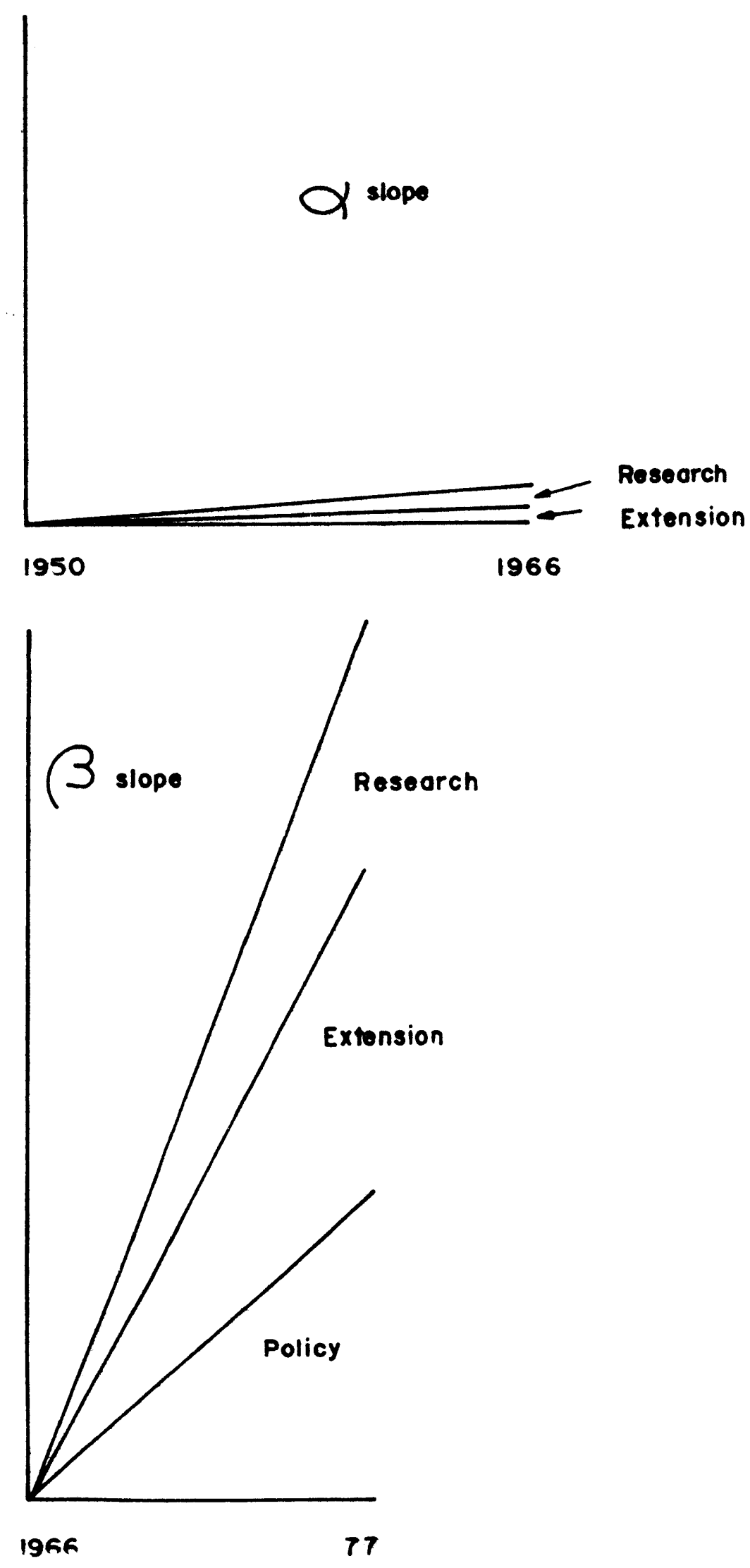

Figure 3 - A tentative breakdown of the factors responsible for fertilizer use. 


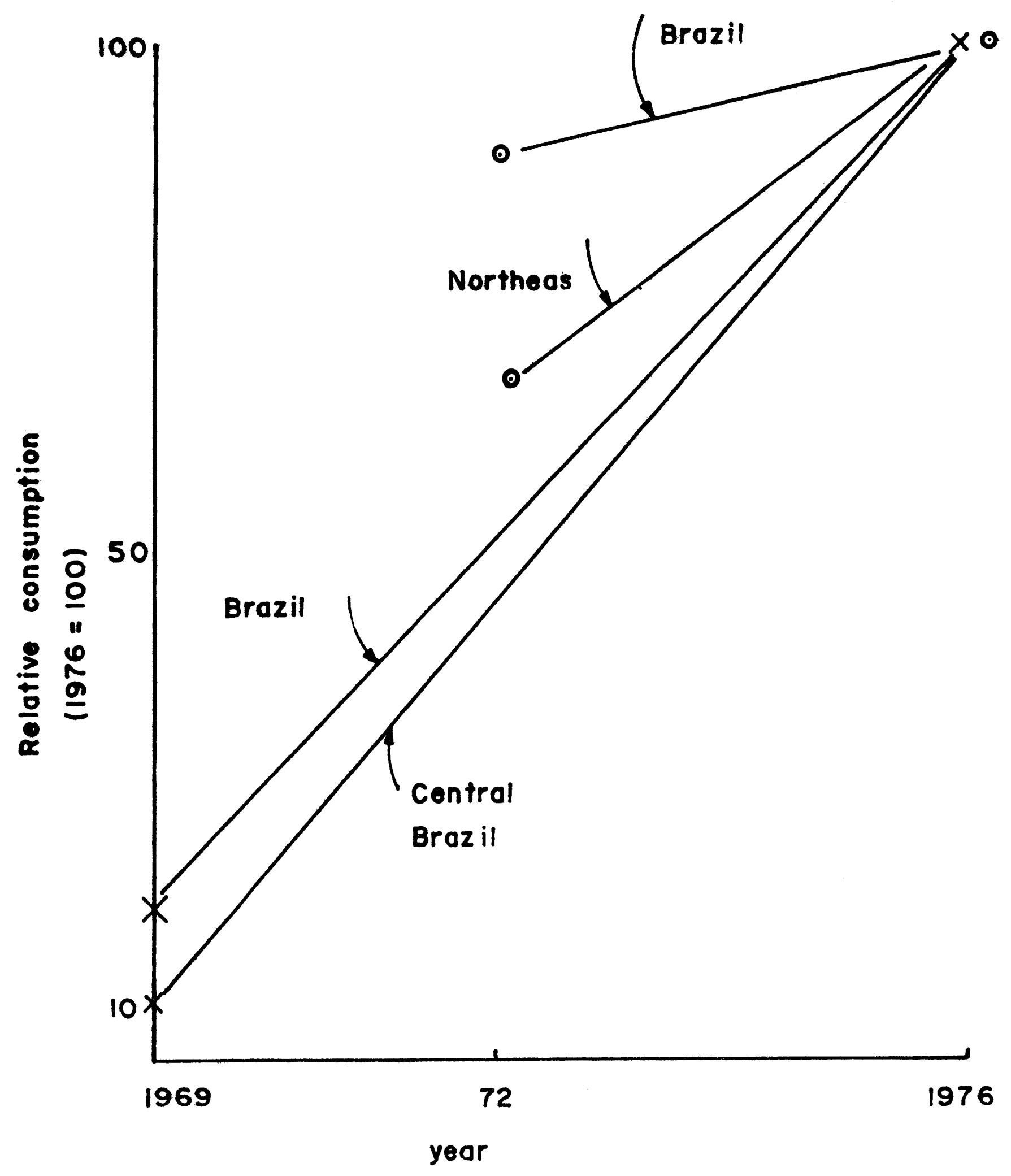

Figure 4 - Evolution of consumption of fertilizers in Central Brazil as compared with total use. 

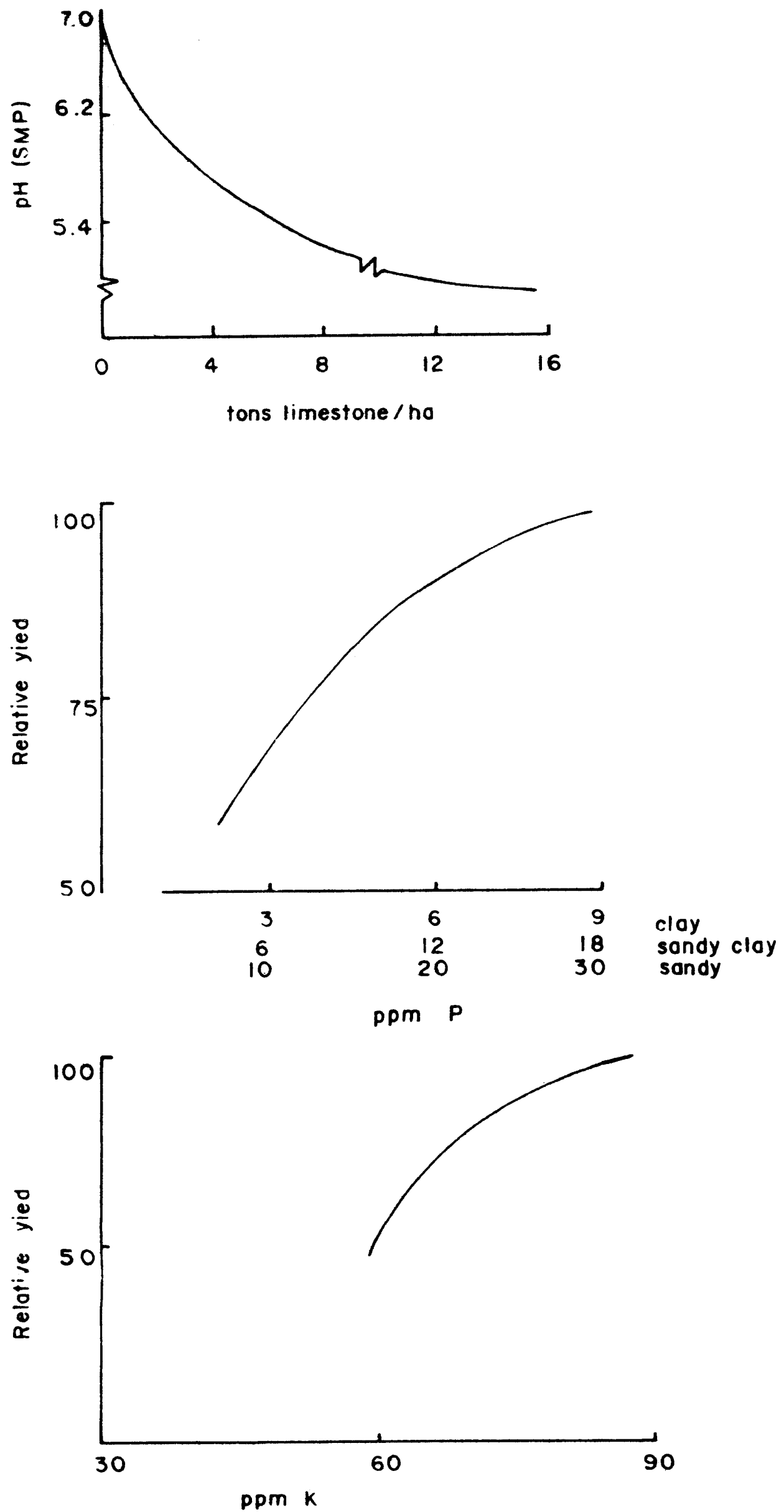

Figure 5-Calibration curves, RS, Brazil. 